Article

\title{
Crows and Ravens as Indicators of Socioeconomic and Cultural Changes in Urban Areas
}

\author{
Karol Król *(i) and Józef Hernik \\ Digital Cultural Heritage Laboratory, Department of Land Management and Landscape Architecture, \\ Faculty of Environmental Engineering and Land Surveying, University of Agriculture in Kraków, Balicka 253c, \\ 30-149 Kraków, Poland; rmhernik@cyf-kr.edu.pl \\ * Correspondence: k.krol@onet.com.pl; Tel.: +48-12-662-40-16
}

Received: 5 November 2020; Accepted: 7 December 2020; Published: 8 December 2020

\begin{abstract}
Crows and ravens are deeply symbolic. They have featured in myriads of myths and legends. They have been perceived as ominous, totemic, but also smart and intelligent birds by various peoples around the world. They have heralded bad luck and evoked negative associations. How are they perceived today, in the time of the Internet, mobile devices, and popular culture? Is the young generation familiar with the legends, tales, or beliefs related to these birds? The purpose of this paper was to determine the place of the crow and raven in the consciousness of young generations, referred to as Generation $Y$ and Generation $Z$. The authors proposed that young people, Generations $\mathrm{Y}$ and $\mathrm{Z}$, were not familiar with the symbolism of crows and ravens, attached no weight to them, and failed to appreciate their past cultural roles. The survey involved respondents aged 60 and over as well. Both online surveys and direct, in-depth, structured interviews were employed. It was demonstrated that the crow and raven are ominous birds that herald bad luck and evoke negative associations and feelings in the consciousness of young generations. The perception of crows and ravens by the younger generation stems mostly from popular culture and the appearance and behavior of the birds. The ways in which crows and ravens are represented in popular culture and perceived by the public may directly affect their fate in areas with human presence.
\end{abstract}

Keywords: symbolism; cultural heritage; folk beliefs; vanishing heritage; urban ecosystems

\section{Introduction}

The population of Corvidae in city centers and fringes has grown in recent years. They often prey on solid waste in easily accessible dustbins or are fed by people. Sometimes, they are so numerous that they displace other bird species and "take control" of an area by occupying vegetation and urban infrastructure. Crows, ravens, and rooks are most often seen by city dwellers in terms of the losses that they cause. Nevertheless, their symbolism and significance in European cultures are abundant. They are related to death, war, disease, and plague. In the past, crows and ravens followed armies and feasted on the bodies of the fallen but also on the corpses of victims of epidemics. They bode poorly. This bestowed the raven with the mythical status of a being between life and death. Swedish folklore saw ravens as the ghosts of murder victims. In many cultures, they were messengers or foresaw the results of battles. The crow and raven were assigned symbolic meanings in other parts of the world as well, such as China, Japan, and India.

They are often found in tales, myths, and legends. Essentially, various peoples around the world have believed them to be ominous, totemic, but also smart and intelligent birds. How are they perceived today, in the time of the Internet, mobile devices, and popular culture? Are crows and ravens still set side by side with a mystical figure who ushers the dead "to the other side"? Do they symbolize and forebode misfortune or death? Is the young generation familiar with the legends, tales, or beliefs 
related to these birds? Do crows and ravens inspire the same awe as in the 19th and 20th centuries? The purpose of this paper was to determine the place of the crow and raven in the consciousness of young generations, referred to as Generation $\mathrm{Y}$ and Generation Z. They were brought up during intensive socioeconomic and cultural changes both in urban and rural areas. The authors proposed that young people, of Generations $\mathrm{Y}$ and $\mathrm{Z}$, were not familiar with the symbolism of crows and ravens, attached no weight to it, and failed to appreciate their past cultural roles.

The first part of the paper provides ornithological and cultural characteristics of the crow and raven. Myths and beliefs related to the birds were described. The authors then analyze motifs of the crow and raven in popular culture, focusing on literature and cinematography. The next step was to provide insight into selected aspects of the occurrence of the birds in cities, the ecosystem functions that they carry out, and the damage that they cause. The next part focuses on the results of the survey and the conclusions that it offers. The hypothesis is then verified with a survey involving respondents aged 60 and over. This determines how older generations perceive crows and ravens.

\section{The Crow and the Raven}

Sociable, impudent, nosy, intelligent, but also mysterious, dark, ominous, "false", cheeky, aggressive, and "thievish", are the words used to describe crows and ravens [1]. The Corvidae family (crows, jays, magpies, and allies) covers 117 bird species found on most continents except for Antarctica. The crow (genus Corvus) constitutes around one-third of species diversity ( 40 species) and can be found on all continents except for South America and Antarctica but also in secluded archipelagos such as Hawaii, Micronesia, and Melanesia [2,3]. The Corvidae is part of the core Corvoidae radiation that contains more than 750 species. Research shows that the core Corvoidae originated from an archipelago north of Australia in the late Oligocene/early Miocene and then spread throughout the world [3,4].

The raven can be found worldwide. It is the largest of the corvids, and its skeletal elements are not difficult to identify. The three other most popular species of large corvids are the carrion crow (C. corone), the hooded crow (C. cornix), and the rook (C. frugilegus). Their skeletal elements are very similar, apart from the skull, which makes them difficult to distinguish [5].

\subsection{Intelligent Like a Crow and Raven}

Crows and ravens have relatively large brains but also better cognitive abilities compared to other birds. Crows are large passerine birds that are considered intelligent because of their flexible behavior, problem-solving skills, and social learning. They belong to the small group of organisms that are considered intelligent. Crows have demonstrated many smart procedures when using tools to access food. For example, crows from Sendai, Japan collect autumn nuts and place them precisely in front of cars that stop before pedestrian crossings. The vehicles then crush the nuts, allowing the birds to feed on their nutritious contents [6]. This behavior has slowly spread from the place where it was first recorded 20 years ago, which is consistent with social learning; crows mimic the behavior of other members of the crow community. Other populations of crows drop nuts from heights to crush the hard shell $[3,7]$. Corvids readily collaborate and are highly selective regarding teamwork partners; they are prudent about their coalitions and alliances [8]. The combination of opportunism and intelligence allows them to adapt to new circumstances well [9].

Crows and ravens are often seen as "close to people" [10]. They are believed to be one of the most intelligent and sociable birds. They are also very capable of adaptation. Ravens can count and calculate [11]. They can deceive, a skill recently reserved for humans and primates [12]. Both crows and ravens can learn, to some extent, to interpret (associate) human speech (to link sounds made by humans to actions associated with them). The birds can even learn to speak and imitate sounds [11]. Moreover, the raven lives for a long time, up to 20 to 25 years. One recorded specimen, a tamed raven, lived for 44 years in the Tower of London $[5,10]$. 


\subsection{Ravens and Crows in Myths and Beliefs}

The unique character of ravens and crows, including their tolerance of humans, their scavenging habits, and their voice, led to their playing an important role in Iron Age and Roman rites and beliefs [5]. Crows and ravens are featured in Indo-European culture in Celtic, Norse, and Greco-Roman traditions and beliefs. In the beliefs and myths of the Celtic peoples of Ireland, the raven and the crow were viewed as part of a continuum. Hence, myths associated with ravens and crows tell the same stories: for instance, the Morrigan, the Irish triple goddess, was sometimes associated with ravens and sometimes with crows [5,13].

Attitudes towards crows and ravens were related to the beliefs associated with the world of spirits and gods. The birds are found in myths, beliefs, and rituals all over the world-for example, in Roman and Celtic mythologies $[5,14]$. The call of the raven was often interpreted as a message from the beyond [15]. The fact that ravens, and, to some extent, crows as well, could "speak" induced many societies to believe that they had the gift of prophecy, particularly of doom. In many cultures, the raven was a powerful totemic bird [5].

In the first millennium BC, it was thought that ravens could foretell the results of battles. A Celtic raven god, Lugh, a god of war, was warned of an enemy by his raven familiars. Raven movement patterns and sounds were interpreted to predict future events [5]. In Norse mythology, ravens could foreshadow future events and symbolized wisdom. Two of them, Huginn and Muninn, were Odin's messengers. The association with Valkyries (Norse female ushers of slain warriors) linked ravens to the theme of war [16].

Past deities, as well as characters in popular culture, often could metamorphose into a raven or crow. Lugh could turn into a raven, just as witches, sorcerers, or Badbh, an Irish goddess who uses a crow form as a spirit. Morrígan (Mor Regan, Morrighan), a Celtic god, could assume various forms, including that of a raven. Morrígan was associated mostly with war and the auguring of death or battle victories. In this role, he would most often come as a crow (Battle Crow) [5].

Thanks to their intelligence, crows and ravens were tamed relatively early and were kept as pets or companions. This practice was reported by Pliny and Macrobius, who described how ravens were kept as pets in Ancient Rome. The same can be seen today in the Tower of London. Some authors use the Roman tradition of keeping ravens as pets as an argument for the proposal that the ravens unearthed in 19th-century excavations at Silchester were pets or even "semi-domesticated" [5].

Tamed birds are considered pets or companion animals, but if they were tamed for ritual purposes, they were "familiars" rather than pets. In many ancient cultures, gods kept a raven or a pair of ravens. This practice was reported in texts on Mithras, but also Apollo, Lugh, and Morrigan. The two raven "familiars" of the Norse god Odin represented thought and memory. They acted as messengers: they flew out each morning and returned in the evening to tell their master about all the events that had taken place that day [5].

Druids and shamans of the Celtic world and their successors, the priests of the Roman world, kept ravens as well. A Gallo-Roman stone relief from Moux, France, shows a man with birds on his shoulders, possibly a shaman with his "helpers". Their size, shape, and posture suggest that they were a pair of ravens. Many works of art depicting a priest with a crow or raven reinforce the association between ravens and priests [5].

Ukrainian Christians linked the Biblical story of Adam and Eve with a black crow. They believed that before the fall, crows used to be completely white and made "sweet", "enchanting" sounds. After Adam and Eve were expelled from Paradise, the birds started eating carrion and consequently turned black and lost their beautiful voices. The crows stand for decline, torment, and misery [17].

Shakespearean poetry offers many references to crows and ravens, most of them unfavorable. In "The Phoenix and the Turtle", he included negative allusions to crows: And thou treble-dated crow. That thy sable gender mak'st. With the breath thou giv'st and tak'st. 'Mongst air mourners shalt thou go. Another example of a negative image of crows and ravens can be found in Macbeth, where a raven symbolizes the amoral actions of Lady Macbeth [17]. 
Crows and ravens are part of Polish culture as well. Polish people believed the raven to be a harbinger of misery, hunger, or death. This image originates from their black feathers (raven-black), relatively sharp and hoarse call, and their scavenger instincts [18]. The dark, even black plumage of the crow and raven reinforced their perception as symbols of death [19]. For some, the croak sounded like "trup, trup!", which is Polish for "corpse". To undo a spell, one could use various incantations (according to Miesięcznik Galicyjskiego Towarzystwa Ochrony Zwierzat, 1878)—for example, "Żebyś przepadł, kruku stary! Mnie nie szkodza twoje czary! W ręku Boga życie moje, twoich wróżeń się nie boję!" (Begone, old raven | Your magic won't hurt me! | My life's in God's hands | Your foretellings scare me not!).

Supposedly, a raven founded an altar in the Cistercians monastery near Kraków (Małopolskie Voivodeship, Poland). It is believed that a tamed bird lived in the monastery and flew to Kraków every so often, returning with jewels from the city. It stored them in a monastery tower. When the time came to repair it, the monks discovered the treasure. As the owner could not be determined, the prior spent it on an altar-hence, the sculpture of a raven at the finial.

Many beliefs and superstitions involved ravens. A raven croaking above a person foretold death. A raven resting on a pasture meant the death of cattle (near Wieliczka, Lesser Poland). In Ruthenia, people believed that the devil created the raven—hence, its color. When the bird learnt to utter several words, it was Satan speaking. Countrymen understood that when a raven called over a person or a house, somebody from their extended family, an animal, or a household member would die.

Ravens heralded misery, war, and sadness. In Red Ruthenia, a mournful croak announced the death of people or cattle. In Belarus, people believed that a diseased person would die if a raven croaked over the house in which they lay. Lithuanian peoples saw ravens and owls as symbols of death and misery. Bulgarians, Latvians, and Romanians also believed that the sound of a raven or crow brought bad luck.

Crows and ravens were symbols of disaster in other countries as well. In Iceland, a raven croaking over an ill person meant that they would die soon, and when a raven landed on a church tower, someone in the community would die. The raven was a harbinger of death and misery in Italy as well. For the Romans, it was a bad omen. The Arabs described it as a "messenger of bad luck". The Babylonian Talmud and third-century Tosefta Shabbat describe raven croaking as a bad sign [18].

Just as the raven, the crow was an ominous bird and was considered an "accomplice of the devil" because of its frightening cawing and black plumage. Old Kashubian beliefs depicted crows as transformed sorcerers or witches. Near the town of Lębork, people believed that "there was a witch within the crow". When a crow cawed over a house, the Polish peasant would curse it: "Caw over your own head." (Osieczany, Myślenice, Lesser Poland). One superstition would have one spit thrice and curse: "May you tear from rump to throat." (near Przeworsk, Podkarpackie Voivodeship). In the Kraków area, crows supposedly had the gift of prophecy: "Warns of death and bad luck with its cawing." In Ukraine and Lithuania, a crow cawing on a roof prophesied imminent death in the family. Near Zamość (Lubelskie Voivodeship, Poland), when crows or jackdaws rested on a field, "devils prepare to snatch a damned soul". If they flocked after sunset, "ghosts flew for a soul sold to the devil" [18].

\subsection{Scavengers}

Both ravens and crows were perceived as scavengers and known for feeding on corpses. This phenomenon was particularly striking after great battles when bodies of the slain were not buried. This affected the perception of crows and ravens and has largely shaped their image to this day [5]. This is reflected in the literature, for example, by Żeromski [20]: "Crows and ravens flew singly and in flocks against the wind, as if to meet the clouds. The birds started circling above the carcass (... ). The crows approached the horse with great caution, tact, patience, and diplomacy, twisting their heads and carefully studying the situation. One ( . . ) marched to the nostril of the killed horse, where a blood clot was still oozing, covered with a reddish membrane. Its sharp, keen eyes noticed what they were supposed to. Then, without thought, the crow jumped on the dead, decrepit horse's head, 
lifted up its beak, straddled it with its legs like a woodcutter setting himself to fell a tree, and struck the corpse's eye, as if with an iron pickax. The other companions followed the example of the bold crow".

Crows and ravens were buried. Corvidae burial sites were found in former settlements, towns, and Celtic defensive settlements in the territory of today's Great Britain. Carrions of birds were most often accompanied by other animal bodies. Intentional burial grounds of crows and ravens from the Iron Age were found in continental Europe as well—for example, in Italy [21], Manching, Bavaria, the Greek island of Poros, or in the Netherlands [22]. Burials of corvids were interpreted in various ways or not at all. Some researchers believed that selected burials were reserved for tamed birds that accompanied people. Others concluded that the birds had been consumed. The interpretation changed with time. Corvids in tombs are increasingly often perceived as part of a burial ritual to propitiate gods and ensure fertility $[5,23]$. The chthonic symbolism must not be neglected here. Birds buried ritually deep underground were a bridge between the living and the dead, the world and powers of the underworld [15]. Ravens' ability to "connect people and gods" was supposed to continue after they died.

Corvids were used as characters in folk tales, smart crooks, both in North American Native stories and Aesop's Fables. In 15th and 16th-century England, crows were considered intelligent, resourceful, and responsible "citizens", "protected by the law for their (communal) services in the streets". Their perception pivoted after the Great Fire of London in 1666. Their scavenger instincts came to light as crows and ravens feasted on charred bodies. King Charles II ordered them to be exterminated. This attitude towards the birds continues to this day [1].

\subsection{The Crow and Raven in Popular Culture}

Crows and ravens are found in cinematography. The best-known film featuring corvids was the 1994 American superhero film The Crow, starring Brandon Lee. In the Polish distribution, the guide, master of the dead, was a crow. It symbolized death and power over death. The vigilante left the mark of the raven on the bodies of his victims or on walls. In the original American version, the bird was the American crow. There were several sequels to the picture.

Popular beliefs concerning ravens and crows framed them as dark characters or "set" for horrors. The Crows by Edzard Onneken, 2006, depicts Germans who are threatened by a plague of aggressive crows, the intelligence of which was boosted by medical experiments. The ominous associations with birds were employed in a famous film by Alfred Hitchcock, the Birds, 1963. It is about a small seaside town under attack by aggressive seagulls, crows, and ravens. Crows and ravens are often used in dramas and thrillers, such as a 1976 Spanish Raise Ravens by Carlosa Saura. The title was based on a Spanish saying, "Cría cuervos y te sacarán los ojos": feed the ravens and they'll peck your eyes out. In a short 2016 drama by Jennifer Perrott, the Ravens, a pair of birds reflect the difficult life of a family struggling to start over after a war. In 28 Days Later (2002, directed by Danny Boyle), a crow literally brings death by spreading a deadly virus wreaking havoc on the streets of London. A crow named Jake is the best friend of one of the characters in The Shawshank Redemption (1994, directed by Frank Darabont). The crow was the main symbol in The Stand (1994). A flock of crows reinforced the menacing image of the queen in a fantasy drama, Snow White and the Huntsman (2012, directed by Rupert Sanders). In famous The Lord of the Rings: The Fellowship of the Ring (2001), a flock of ravens are servants of the evil and spy for Sauron (Sauron's Crebain).

Rozdziobia Nas Kruki, Wrony (Ravens and Crows Will Peck Us to Pieces) from 2000 by Jan Holoubek is an example of a Polish film with birds as its theme. It is an adaptation of a short story by Stefan Żeromski, which depicts the tragedy of the 1864 January Uprising in Poland. Another interesting proposition is the 1994 drama Wrony (Haunting Strangeness) directed by Dorota Kedzierzawska. The theme is loneliness and longing for love. These films make use of the dark and ominous reputation of the raven and the crow as birds associated with evil, death, sadness, and misery. The topos of these works is the reflection on the fate of people who are weak, helpless, rejected, or stigmatized by life. 


\section{Birds in the City}

Urbanized habitats differ from natural ones in several ecological features, including climate, food availability, strength of predation, and competition [24]. Birds that live in cities are the best-investigated group of animals from urbanized areas. They are popular with researchers thanks to such features as their relatively significant diversity, large population, wide distribution, ease of observation, large call variability, and feeding preferences $[25,26]$.

Bird species from urban areas can be categorized as synanthropic (associated with humans and partially dependent on them) and synurbic species (living in urbanized areas independently of humans). They all have adapted to urban life by developing many behavioral, physiological, morphological, ecological, or sometimes even genetic adaptations for survival in an urban environment [27].

The city offers abundant opportunities to birds. They take advantage of waste and feeding. Buildings and structures provide shelter and room for nesting. Urban greenery such as parks, squares, and lines of trees and shrubs also provide shelter. Cities are also relatively safe for birds, which has resulted in some avifauna populations growing so large that they have started to become troublesome-flocks of pigeons or rooks in soil façades, urban infrastructure, and cars. Urban pigeons can spread ticks and zoonoses. This can cause conflicts between people and birds. Some human activities threaten birds. Large-scale thermal insulation projects and clearing of trees and shrubs can lead to loss of breeding habitats. Sometimes, birds are killed by fast-moving cars [27]. Nevertheless, birds provide many ecosystem services to the residents of cities.

\subsection{Ecosystem Services Provided by Birds}

Ecosystem services are profits which people gain from ecosystem processes [28]. The concept of ecosystem services binds human quality of life with the condition of ecosystems. The four main categories of ecosystem services are (1) provisioning (provision of products to be used by people directly), (2) regulating (regulation of the condition of the human living environment), (3) habitat (creation of human living environment), and (4) cultural (cultural value of nature) [29].

The ecosystem services approach can be applied to birds as well [26]. These services are provided by the ecosystem and result from its functions, so birds are considered a component necessary to generate benefits for people. They can often be linked to specific species and their roles in the ecosystem. Probably, the most emphasized ecosystem service provided by birds is pest control. Their role in tourism and recreation (birdwatching) and their symbolic meaning are appreciated as well. Other benefits of bird presence include pollination or the removal of organic waste such as carrion [25,26].

Green areas are important for the urban ecosystem. Their functions include leisure, recreation, health, aesthetics, but also shaping and maintaining biodiversity. The latter is often neglected or downplayed, but it brings numerous benefits. Appropriate tree formations contribute to nesting, which has numerous advantages for the urban environment. The key is the control of the populations of insects that people find irritating and insects that threaten some tree species planted in cities. Bird song adds natural variety to the urban hustle and bustle. Birds also make the city appear more friendly and rustic to its inhabitants [27].

\subsection{Ravens and Crows in the City}

Corvidae have impacted human culture significantly. The human potential to shape the behavior of corvids is impressive as well [7]. Human settlements have always brought birds and people together. Crow, raven, and human remains were found in ancient records on settlements in Syria, Poland, Troy, Mesopotamia, and Canada dating back four or even ten thousand years [30]. Ravens are known to have acted as scavengers, cleaning up towns in the Roman period and, with red kites, were encouraged to do the same in medieval towns [10]. The cultural coevolution of corvids and humans is apparent today as well, both in urban and rural areas. It is evident in their behavior, diet, and feeding methods [7]. 
The main food source of ravens in the countryside was carrion [10]. Crows also devoured any leftovers left by predators and humans. For this reason, ravens and crows have been found in human settlements since the early periods of history [5]. When the prehistoric men learnt to hunt, crows and other corvids such as ravens, magpies, and jackdaws started flocking up near human settlements, taking advantage of potential food sources. Other scavenging birds also gather around people, but none is as attentive as the crow. Seagulls and pigeons, for example, do not watch human behavior as closely [1].

\subsection{Safeguards against Bird-Induced Losses}

Urban infrastructure often needs to be protected from the negative impact of birds. There are two groups of devices used as bird protection in cities: (1) deterrents such as sound systems, models, and figurines of birds of prey and (2) protective devices that prevent birds from staying in a place and nesting. Façades are most often protected with bird spikes (Figure 1) made from flexible stainless steel wires [31]. These blunt-tipped wires are fixed to a transparent base that is resistant to sunlight, weather conditions, and high temperature. The spikes form an anti-roosting and anti-nesting barrier (Figure 2). Bird spikes are used all over the world because they are very effective, relatively affordable, and easy to install. Sometimes, the spikes can be accompanied by bird coils. They consist of wire bent into round or oval shapes fixed to a plastic holder. Placed closely together, the components make a coil. Other effective solutions include nets, which yield good results with balconies, recesses, façade corners, roof structures, and other façade features [32]. Nets are also successful in protecting fruit and vegetable crops [33]. They work well for protecting the lower parts of garden shelters, roofing, and other similar places. Nets are made of various materials, such as polyethene.
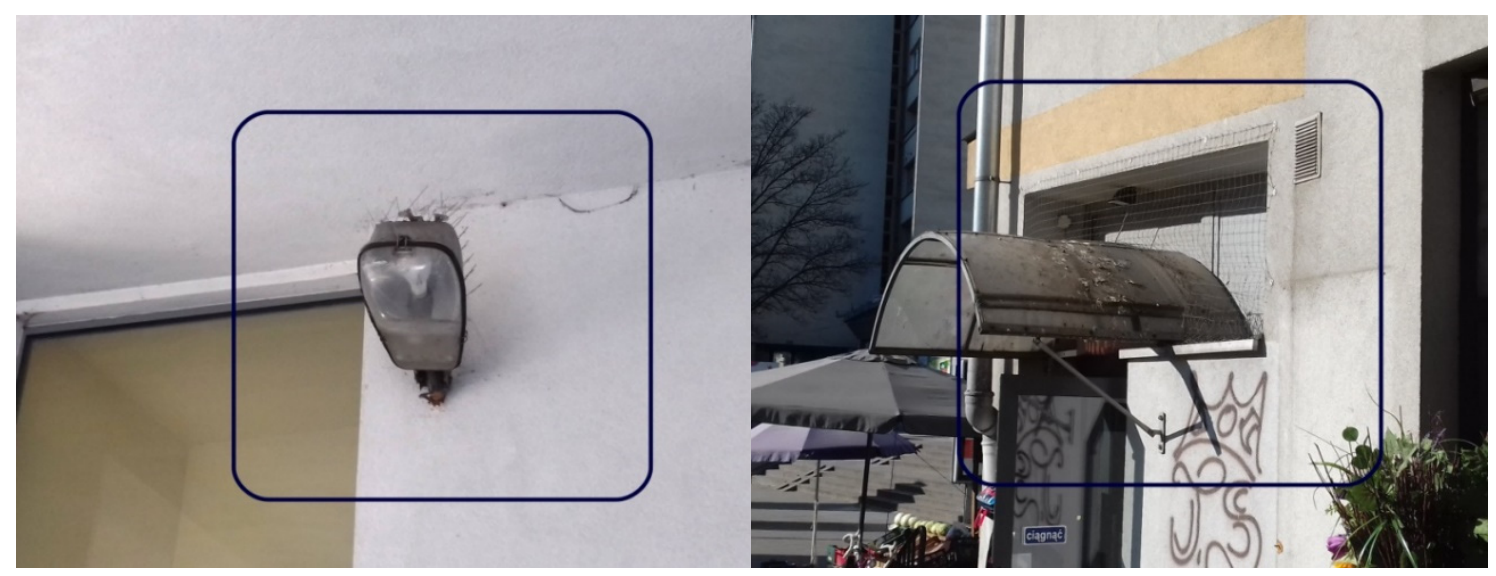

Figure 1. Bird spikes protecting urban infrastructure: lighting and roofing. Photographs by: K. Król.

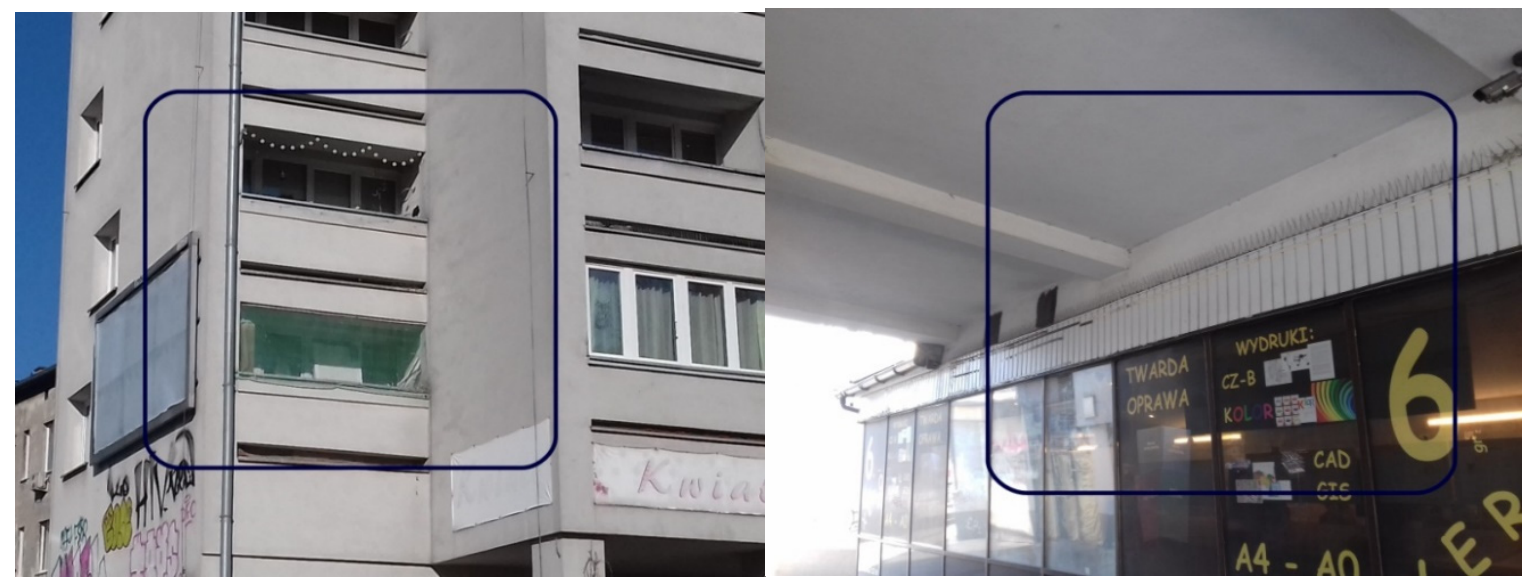

Figure 2. Bird spikes protecting urban infrastructure: balconies and cornices. Photographs by: K. Król. 
Railings and other narrow spaces can be protected with bird spike mats. The spikes are dense and set conically, which improves their effectiveness. The mats protect fences, walls, cornices, and windowsills against such animals as birds, cats, martens, or squirrels. Another solution is rotating rods or birdwire. They are most popular for windowsills and balcony railings. Fixed mechanical solutions are often complemented with electronic devices that generate sounds of birds of prey or ultrasounds.

Sometimes, façades and balconies are guarded by cast or molded ravens or raptors. The drawback is the static form. Birds quickly grow accustomed to the immovable silhouette, and its effectiveness drops in a few days (Figure 3).

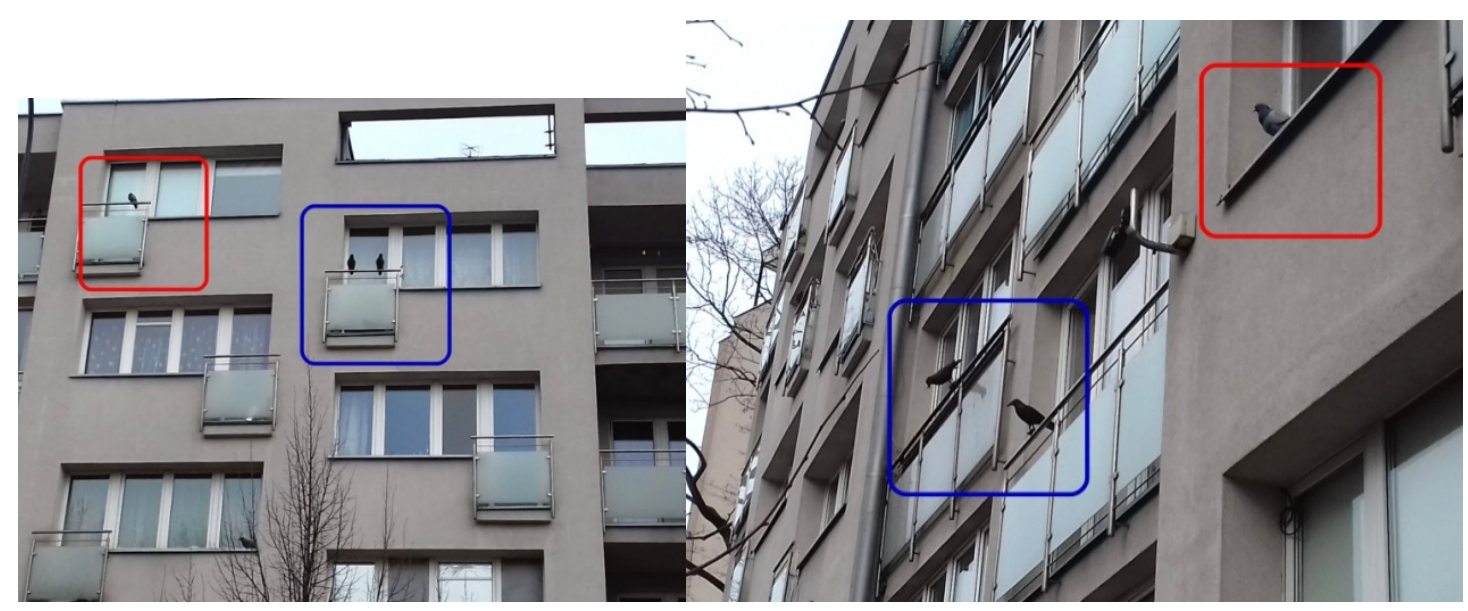

Figure 3. Urban pigeons on balcony railing near artificial birds. Decoy ravens are marked in blue. Pigeons are marked in red. Pigeons roost at a safe distance from the artificial raven. Photographs by: K. Król.

Some raven figurines resemble the bird mid-flight. They can be hung from a branch or a hook fixed to a flat surface. The wind improves its effectiveness by causing it to swing. Such imitations should be fixed in easily visible locations. The number of scarers is important as well. It should be sufficiently large to cover the protected area. Stickers with shapes of ravens or birds of prey are another popular solution. They are most often used on glass wall buildings to prevent birds from hitting the solid surface [34]. They can be found on noise barriers along highways in and outside cities as well as on any other glass or reflective surfaces (Figure 4) [32].

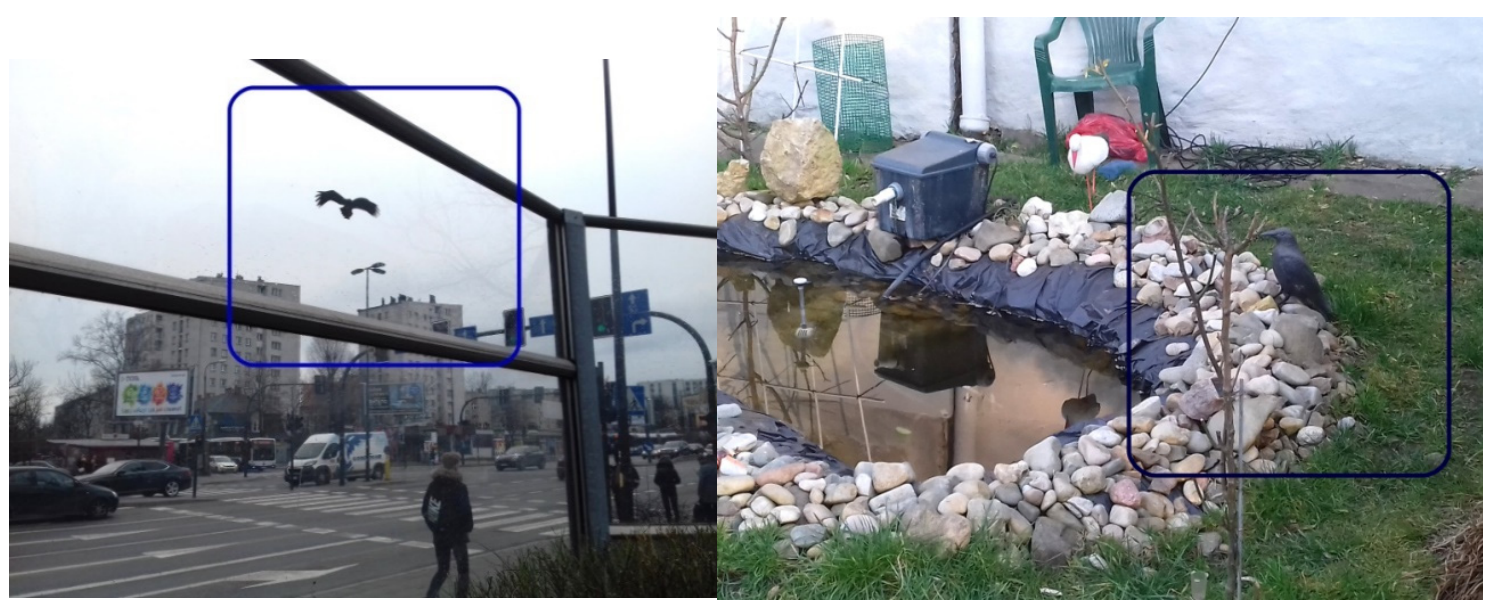

(a)

(b)

Figure 4. Noise barriers (a) with a bird silhouette sticker (29 Listopada Ave., Kraków) and a raven-shaped bird scarer in a garden (b). Photographs by: K. Król. 
Another category is gel systems. They contain natural foodstuffs that keep birds at bay. The gel discourages birds with ultraviolet light. A vegetable oil boosts the optical deterring properties that birds dislike.

\section{Materials and Methods}

The paper is part of a series titled "Rural and urban cultural heritage" [33]. The paper was developed under a research framework focusing on socioeconomic, environmental, and cultural changes. It seeks to identify indicators of cultural change in urban and rural areas. The changes are caused by social, economic, and technological development. Some of them involve changes in the perception of cultural heritage assets, which results in the cessation of protection of the cultural components, including tangible and intangible ones.

The online survey (questionnaire address: http://bit.ly/kruki-wrony) was conducted at two universities, in Kraków and Gliwice (Figure 5). It involved 425 respondents from Generations X and Y. Such sampling facilitated some insight into the entire population. The size of the sample was sufficient for statistically valid conclusions for the whole population for the assumed maximum statistical error rate of the sample of $\pm 5 \%$ and the confidence level $p=0.95$.

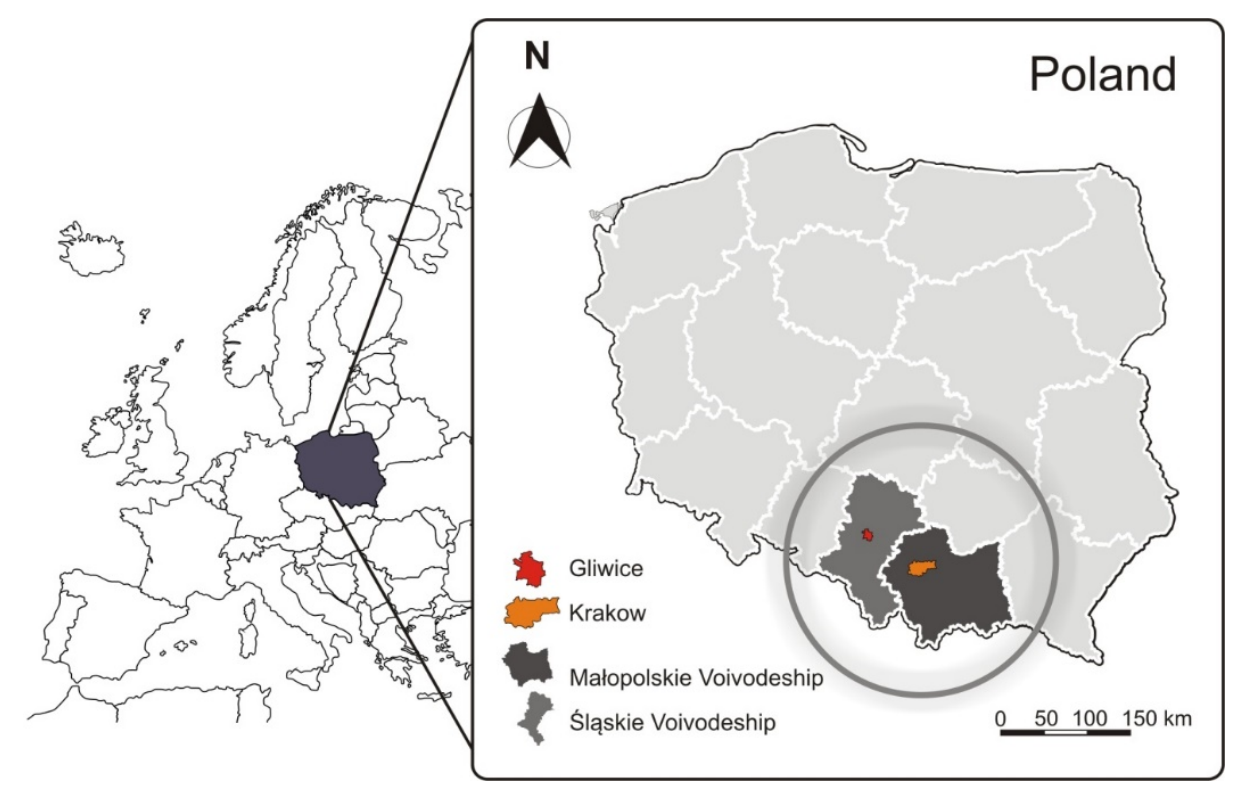

Figure 5. Locations of the research centers where the survey was conducted. Source: own work.

The survey was conducted in stages in March and October 2020 in computer rooms and during online meetings (using Microsoft Teams) supervised by the authors. The respondents included first and second-year full-time students at the University of Agriculture in Kraków and Silesian University of Technology in Gliwice. Additionally, the authors conducted thirteen direct, structured, in-depth interviews with students of the University of Third Age (60 years and older).

Only thirteen seniors participated in the survey because of the COVID-19 pandemic. The authors had several hundred copies of the questionnaire ready for a meeting with University of Third Age students arranged in advance. However, due to the pandemic, it was not possible to acquire a larger sample.

Data may be obtained on the Internet more quickly, globally, and cheaply. Online questionnaires are gradually displacing popular paper-and-pencil (PAP) surveys [35]. A pilot study demonstrated that young people preferred the online questionnaire, which they handled easily. The part involving Generations $Y$ and $Z$ was, therefore, conducted online. For people aged 60 and over, the opposite was true. According to the pilot study, they preferred PAP forms and in-depth interviews. 


\subsection{Respondents}

Every generation has its habits, preferences, and inclinations. These are determined by access to new technologies, sociocultural environment, value systems, and age. The literature offers five general generations (Figure 6) [36]. Classification to a specific generation based on the date of birth is conventional. It depends on multiple factors such as the country, its political system, geopolitics, economic factors, and access to new technologies, including mobile devices and the Internet [37]. Generational understanding does not take the place of concern for the individual. Different generations care about different approaches to the same problem. Different is neither right nor wrong, just different.

Builders,

Matures, Silent

Generation

(1925-1944)

Generation X

(1965-1979)
Generation Z,

Generation C $(>1995)$

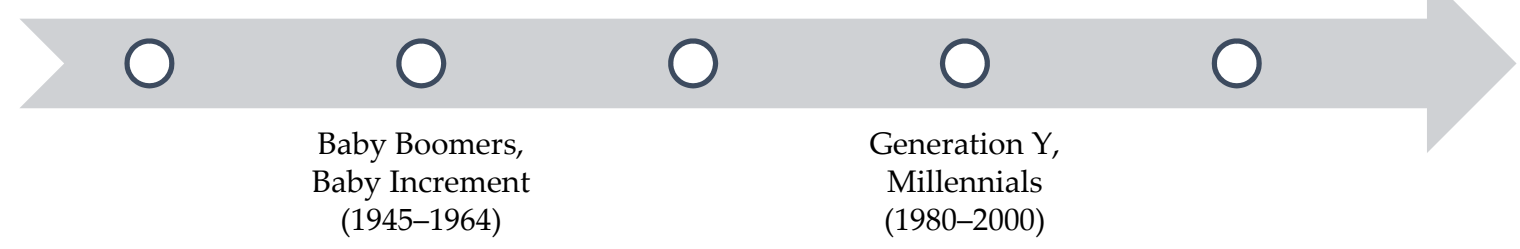

Figure 6. Generations divided by date of birth. Source: own work based on [36].

Generation Y is assumed to include people born from 1980 to 1990. In Poland, Generation Y includes those born between 1980 and 2000. They are further categorized as younger (born from 1990 to 2000) and older (born from 1980 to 1989). The division is founded on the premise that one of the factors shaping Generation $\mathrm{Y}$ is the experience of capitalism and new technologies. The Poles partook in this world after the fall of communism in 1989.

Research shows that from Generation Y come multitasking employees ready to take up new challenges. They can be very dedicated to their work as long as they find it interesting. They value flexible work hours and look for jobs that are well paid and offer professional development opportunities [38,39]. Generation $Y$ is dubbed the digital generation as well. Its members are active users of digital media and technologies.

As opposed to Generation Y, which was introduced to the digital world gradually, Generation Z has always lived in it. Generation $Z$ grew up in the world of modern technologies [40] and finds information online. This generation expects to find information quickly. Its members are oblivious of the world without technology and are driven to affect their surroundings. Generation $\mathrm{Y}$ is believed to consider modern technologies and automatization the norm [41].

The general belief is that Generations $\mathrm{Y}$ and $\mathrm{Z}$ have been gradually growing apart as they seldom contact people from other generations (parents excluded). They do not look for authorities. They believe "everything is in their hands and no-one can force them". Generation Z is sometimes referred to as Generation $C$ (for connected). This is because of their frequent use of the Internet and social media for private and professional communication [42].

Seniors aged 60 and older were born from 1945 to 1964 (Baby Boomers). They respect authority, are very committed to work, and have a strong urge to affiliate. The youth of Baby Boomers coincided with economic prosperity, increasing consumption, and social changes. Devices that they found around them included the TV, radio, and radio cassette player. They came across modern technologies as experienced employees or after retiring [43]. Seniors were the least numerous group of Internet and new technology users. They generate a mere $11 \%$ of all site visits and spend online a little over half the time of 40-year-olds [44].

\subsection{Surveys}

Questionnaire surveys have long been used in social science research. Lately, online surveys of college students have become a widely used method, particularly in studies on online behavior [45]. 
The World Wide Web (WWW) is increasingly being used as a tool and platform for survey research. Online surveys are among the primary research tools used by businesses, schools, universities, research centers, and other investigators. They facilitate quick and precise investigation among a large number of respondents [35]. This is true for public opinion polls and many other research types, such as customer satisfaction surveys, mystery customer, candidate experience, etc. Moreover, online surveys are often employed in interdisciplinary research on socioeconomic and cultural development in its broadest meaning [46,47]. The prevalence of online surveys stems mostly from their accessibility, low cost, multimedia potential, and universality [48].

The present research employed both an online survey and a classic paper-and-pencil survey completed during a structured in-depth interview. The survey questionnaires contained questions about associations and experiences with ravens and crows; knowledge of legends, myths, and superstitions related to Corvidae; observations of ravens and crows; and their place in popular culture.

The survey involved students. Online surveys with students have grown more popular in the recent years. This can be seen in statistics provided by LaRose and Tsai [45]. Half of the twenty survey research projects published in the Social Science Computer Review from 2009 to 2012 employed online questionnaires. Three of them had students as respondents. Nineteen out of 34 questionnaire surveys published in the Journal of Computer-Mediated Communication from 2009 to 2012 were based on online questionnaires, and eight of them involved a student population. Fifty-nine out of 115 questionnaire surveys published from 2009 to 2012 in Cyberpsychology, Behavior, and Social Networking used online forms. Students participated in 23 of them.

\subsection{Result Presentation}

The results are presented in figures and tables. The graphic representation of the results employed the word cloud. The word cloud is a compact, spatially limited representation of a set number of keywords. The words that occur most frequently in the set are shown in a larger font. As the frequency of a word grows, it is more exposed in the word cloud. The word cloud can be of various shapes and colors, but its primary purpose is to represent the frequency of keywords in a source text or a set of words.

\section{Results}

The online survey involved 425 respondents from Generation $\mathrm{Y}$ and $\mathrm{Z}$ (Table 1). The surveyed population consisted of 180 men (42.4\%) and 245 women (57.6\%). Although both women and men participated, the results were analyzed in aggregate. The authors assumed sex to be of secondary importance for the researched phenomenon.

Table 1. Age of respondents.

\begin{tabular}{ccccc}
\hline Generation & Seniors & Generation Y & Generation Z & \multirow{2}{*}{ Total } \\
\cline { 1 - 4 } Age & Born 1940-1960 & Born 1980-1999 & Born 2000-2002 & \\
\hline Number respondents & 13 & 235 & 177 & 425 \\
Percentage (\%) & 3.1 & 55.3 & 41.6 & 100 \\
\hline
\end{tabular}

The respondents were from urban and suburban but also rural areas (Table 2). The total share of respondents from urban and suburban areas was $63.5 \%$.

Table 2. Respondent background (where they were brought up).

\begin{tabular}{ccccc}
\hline Age & Urban & Rural & Suburbs, Outskirts & Total \\
\hline Number respondents & 222 & 155 & 48 & 425 \\
Percentage (\%) & 52.2 & 36.5 & 11.3 & 100 \\
\hline
\end{tabular}




\subsection{The Symbolism of the Crow and Raven}

Only $21.4 \%$ of the respondents (91 people) had positive associations with crows and ravens. Twenty respondents had no associations with the animals. The vast majority (78.6\%, 334 people) declared that the raven evoked negative associations first. This is reflected in the perception of the symbolism of the birds.

The respondents believed that crows and ravens symbolized first and foremost death, but also wisdom. The birds are bad omens and symbolize bad luck. According to the respondents, the symbolism of the crow and raven was pejorative and related to the apocalypse. The most popular keywords assigned to crows and ravens were death, misery, war, and evil. The birds were further described as symbolizing falseness, cunning, and deviousness (Table 3). Many respondents admitted to anxiety or even fear of being physically attacked by crows or ravens. They emphasized that the feelings were related to the build and appearance of the birds, particularly the deep black plumage. The raven was described as a strong and dominant bird. Apart from this negative symbolism, the "young generation" respondents associated the crow and raven with intelligence, wisdom, and intellect. Nevertheless, the birds used their assets "in service of evil".

Table 3. The frequency of selected keywords describing crows and ravens.

\begin{tabular}{ccccccccc}
\hline Keyword & pestilence & disease & darkness & war & death & cemetery & misfortune & evil \\
\hline Frequency * & 9 & 17 & 12 & 18 & 122 & 12 & 59 & 39 \\
\hline Keyword & $\begin{array}{c}\text { intellect/ } \\
\text { intelligence }\end{array}$ & freedom & wisdom & courage & strength & reliability & cunning & valor \\
\hline Frequency * & 12 & 3 & 9 & 1 & 3 & 1 & 5 & 1 \\
\hline \multicolumn{7}{c}{ * based on responses. }
\end{tabular}

The respondents associated crows and ravens with theft, wickedness, trouble, dread, and noise. According to them, crows and ravens were mysterious birds accompanied by gloom, "cold" birds symbolizing autumn rains and the chill of winter mornings. These associations are inherently related to the perception of crows and ravens as harbingers of disaster. The respondents interpreted the birds as symbols of war and bad news. They symbolize death. Death was the first association with crows and ravens for almost $30 \%$ of the respondents (Figure 7). They were also associated with black magic, cemeteries, darkness, hunger and disease, sadness, bad luck, and carrion. At the same time, the respondents associated them with strength, wisdom, courage and protectiveness, reliability and self-control, or even calculation. They also symbolize freedom and cooperation. These associations were much rarer, however.

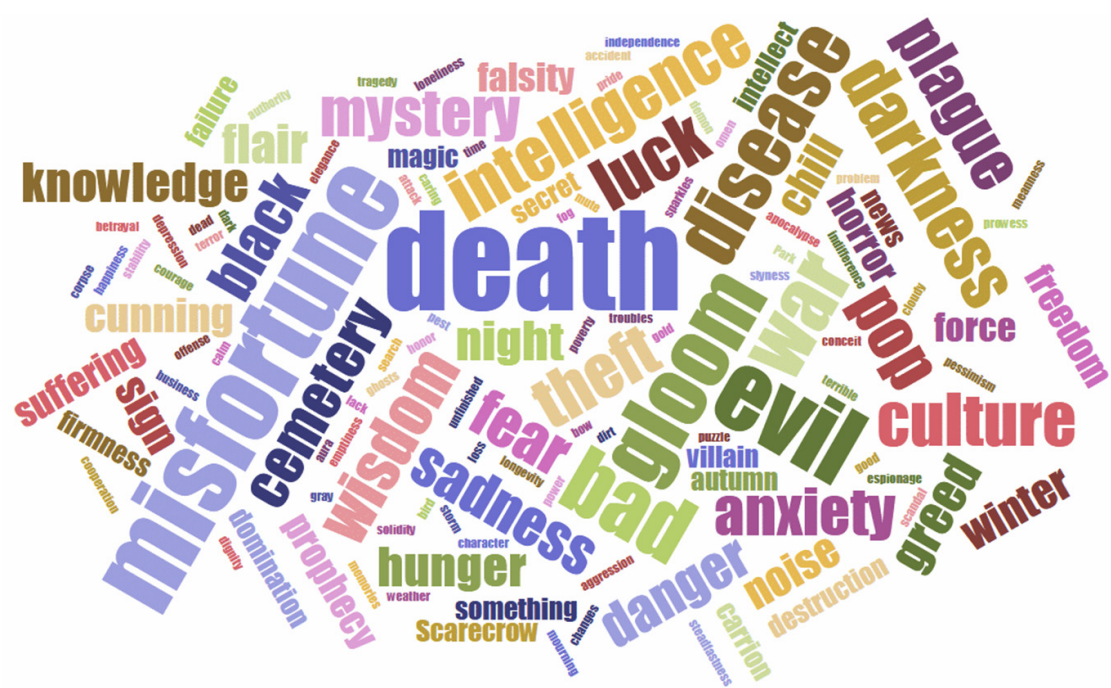

Figure 7. Word cloud—-the frequency of keywords describing crows and ravens (based on survey responses). 
The respondents referred to the role of crows and ravens in popular culture. They emphasized that the birds often symbolized villains and forebode death. The crow and raven are used in dark scenes, horrors, on cemetery sets, in dark alleys, or forest gloom.

\subsection{Legends with Crows and Ravens}

Most of the respondents had no negative experiences with crows or ravens. Only 18 respondents from Generation $\mathrm{Y}$ and $\mathrm{Z}$ reported direct contact with the birds. Many respondents pointed out that they had come across crows or ravens in computer games, films, TV series, comic books, and books. Some respondents had "saved" an injured bird by taking it to the veterinarian. Several respondents from rural areas recalled that the birds had fed on fruit crops, and they associated them with lost crops and scarecrows.

Around $68 \%$ of respondents from Generation $\mathrm{Y}$ and $\mathrm{Z}$ from urban areas admitted to not knowing any legends, myths, superstitions, or rituals relating to crows or ravens. The others were able to describe such legends or superstitions. Some of these are given below:

Respondent 1: I learnt this story from a film where a raven symbolised a man who had unfinished business in this world and needed closure to go in peace.- - the raven symbolises a link between life and death here.

Respondent 2: If a raven croaked over someone's head or house, their family or household member would die. - the raven as a harbinger of misery, a symbol of death.

Respondent 3: When among crows, caw like a crow.-a Polish saying equivalent to 'When in Rome, do as Romans do'. When one enters a social group, they should respect its principles.

Respondent 4: A raven flying and croaking on the left-hand side bodes death or bad spell.- the raven as a harbinger of misery, a symbol of death.

Respondent 5: Do not look ravens straight in the eye or they will peck out yours.- ominous perception of the raven.

Respondent 6: When many ravens gather in one place, they augur bad luck / misery. When crows fly too close to a house, they foretell a disaster. If many ravens perch on a house / block of flats, someone there will soon be taken ill or die. If a raven croaks three times, it forecasts death. When a raven smashes into a window, it bodes misery.-the raven as a harbinger of misery, a symbol of death.

Respondent 7: No raven will pick another raven's eye.-a Polish saying equivalent to 'dog doesn't eat dog'. People brought together by shared interests will not oppose each other.

Many respondents from Generation Y and Z knew the 1895 novella by Stefan Żeromski, "Rozdzióbia Nas Kruki, Wrony", which was a compulsory reading at school. They also pointed out the description of crows and ravens in Adam Mickiewicz's "Dziady" (art II). Here, crows and ravens are associated with gloom as well. Dziady is a folk ritual for All Souls' Day (Day of the Dead). Another work of art recalled by the respondents was a fable by Ignacy Kraciski, "Kruk i Lis" (Aesop's "The Fox and the Crow"), which is also taught in Polish schools. The raven (or crow) symbolizes vanity, which helps the fox trick the bird. Other respondents pointed out the legend of King Krak, a legendary Polish ruler who established the city of Kraków, believed to be the point of origin of the Polish state. According to the legend, the name of Kraków derives from the kraa sound made by ravens which gathered to feast on the corpses of slain warriors.

Generation $\mathrm{Y}$ and $\mathrm{Z}$ respondents mentioned the fourth part of the Raven Cycle by Maggie Stiefvater, the Raven King. Ravens reinforce the dark and mysterious atmosphere of an "enchanted forest" where the main characters travel. The Raven King is associated with evil powers, mystery, the world of the dead, but also power and strength. The respondents also pointed out the "Legend of Poznań Raven King". Poznań sits on the Warta River in Western Poland. The legend tells of a boy, the son of a city guard, who is on the lookout for the enemy army on the town hall tower. One day, he saves a raven from certain death. This turns out to be the raven king. The boy is given a silver trumpet with which to call for the raven king's help. When one day the city is besieged, the boy uses the trumpet. A mighty flock of ravens fly in and drive the enemy away. 
Generation $\mathrm{Y}$ and $\mathrm{Z}$ respondents were aware of Japanese mythology and the figure of Yatagarasu, the envoy of the sun goddess Amaterasu is represented as a three-legged crow or eight-span crow. Moreover, the respondents perceived crows and ravens as inseparable associates of villains such as witches or sorcerers. The respondents knew the story of ravens from the Tower of London- "If the ravens leave the Tower, the kingdom will fall ... "-and Norse myths about Odin's ravens. Interestingly, the respondents pointed out Biblical texts with ravens and the Corvus constellation. This is connected to the myth of Greek god Apollo, where a raven was an important actor. The raven was punished with "eternal thirst" and a hoarse voice for its deception. The raven was also mentioned as a companion of a Horseman of the Apocalypse and a companion of Death.

Although many Generation $Y$ and $Z$ respondents knew stories, myths, and legends about crows and ravens, only 21 of them admitted to "believing in the stories". The other respondents perceived them more as curiosities or elements of literature and folklore. The 21 respondents were then asked to elaborate on their responses. Most of them said that there is always a grain of truth in legends/myths. The other respondents clarified that they did not believe in superstitions and mythology. Moreover, they pointed out that "in the past, people liked to explain various events and connect them to persons/animals/phenomena that were simultaneous but unrelated, rather coincidental." The respondents believed that negative associations with ravens and crows stem from their appearance, and legends (such as the Tower of London) cannot be accounted for rationally.

\subsection{Crows and Ravens in the Lives of City Dwellers}

Seventy-one Generation $\mathrm{Y}$ and $\mathrm{Z}$ respondents (16.7\%) did not notice any impact of crows and ravens on the lives of people and animals residing in cities. Two hundred and forty-eight $(58.4 \%)$ respondents did not have an opinion on this matter. One hundred and six $(24.9 \%)$ respondents believed that crows and ravens did impact the urban ecosystem.

The most common associations with the presence of crows and ravens in cities were "territorial expansion", their role in the food chain, and culture. According to the respondents, crows and ravens attacked smaller birds and "stole" eggs from the nests of other species, and this was why their models could be used to deter such species as pigeons. At the same time, the respondents noted that the birds ate food waste and carrion, reduced urban populations of insects, but might spread out waste from dustbins. Some respondents believed that certain people could find cawing irritating. Most of the respondents stated that crows and ravens were noisy; for others, the sounds were "intriguing and interesting".

Generation $\mathrm{Y}$ and $\mathrm{Z}$ respondents stated that crows and ravens could evoke negative emotions in the residents of cities or even scare passers-by. At the same time, 85 respondents had not noticed crows or ravens near their homes, and 93 had not paid attention to avifauna.

Not many respondents pondered the role of birds in urban ecosystems. Only 26 of them believed that the impact of crows and ravens on life in urban areas had changed. Some supposed that the growing population sizes in cities had been caused by food availability. Another group of respondents had noticed smaller populations of not only crows and ravens but birds in general.

\subsection{The Crow and Raven in Popular Culture}

One hundred and eighty-three respondents from Generations $\mathrm{Y}$ and $\mathrm{Z}$ noted that crows and ravens had been often used in works of popular culture. They listed popular literature books that featured crows and ravens. They proposed such titles as White Raven (by J.L. Weil), the Raven Heart cycle (by Maria Zdybska), Six of Crows (by Leigh Bardugo), the Raven (by Edgar Allan Poe), or Bardzo Biała Wrona (very white crow) (by Ewa Nowak). Most of them belong to speculative fiction, fantasy, or science fiction, where the crow or raven are metaphysical but not necessarily pejorative.

Sometimes, the image of crows and ravens in popular culture is ambiguous, balancing between good and evil. On the other hand, some respondents felt that crows and ravens were represented only as "merciless, aggressive birds", which successfully built tension in dramas or horrors. Many respondents 
listed crows and ravens as "characters" in such films as The Crow or Game of Thrones (three-eyed crow) or video games such as The Longest Journey. The respondents expected crows and ravens to be important for the video game industry, which depicts them as intelligent and baleful creatures. Furthermore, the birds were said to be tattooed often or used in logos, which results in their frequent reception from posters or covers of books or $\mathrm{CD}$ albums. They are also present in theatre and music. They can inspire, for example, "darker" hip-hop such as in "Love Forever" by Słoń.

\subsection{In-Depth Interviews}

Respondents aged 60 and over suspected that the perception of crows and ravens depended on the historical period. They felt that people who lived in and before the 19th century passed on legends to new generations and strongly believed in them. According to the respondents, this practice could be seen in the early 20th century, but it had been then that the belief in superstitions and legends had started to decline (Figure 8). Nevertheless, some rural residents from the beginning of the 20th century were convinced of the "causative power of crows and ravens".

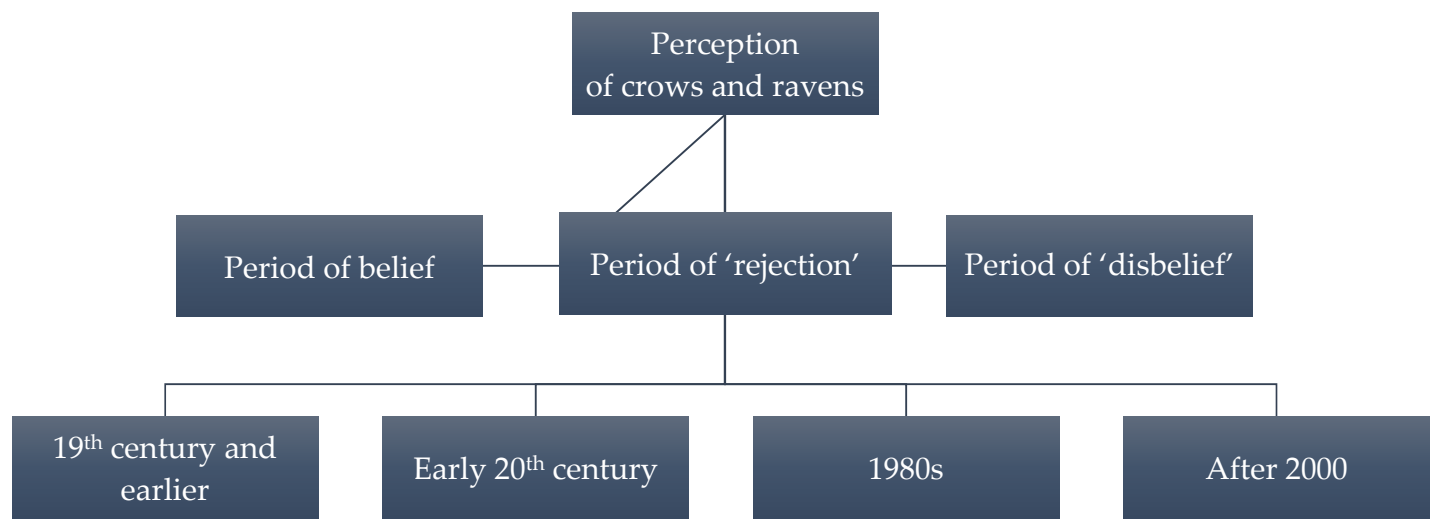

Figure 8. The evolution of the perception of crows and ravens according to respondents aged 60 and over.

The generation of today's 60- year-olds is familiar with some superstitions and legends connected to crows and ravens but strongly "refuses to believe in them".

\section{Discussion}

Crows and ravens are often perceived as birds of prey capable of controlling populations of other species. It has been demonstrated that popular beliefs concerning the attitudes of crows and ravens to other birds are exaggerated. Research shows that egg theft and disturbance in populations of other birds are not a commonplace behavior of corvids. Their impact on the sizes of populations of other birds is, therefore, negligible [49]. The responses demonstrated, however, that crows and ravens are still perceived as "aggressive" towards other birds. This opinion is deeply rooted.

Crows prefer open space, agricultural fields, and house lawns, while songbirds prefer thicket. Research shows that small lawns enclosed by trees and shrubs are popular with small songbirds and less so with crows and ravens [1]. It may be that the way in which urban space is developed contributed to the fact that some respondents seemed not to notice crows or ravens near their homes.

Humans are usually disgusted by the diet of crows and ravens, which includes waste, carrion, and chicks. Nevertheless, Corvidae function as a cleaning service both in urban and rural areas. Note that such animals as raccoons or snakes consume many more songbirds than crows. Crows reduce pest populations [1]. The respondents pointed this out as an advantage of their presence in urban environments.

The population of American crows is growing, which is affecting landscape changes. Crows flock on agricultural land, in the suburbs, and in cities. A greater amount of solid waste, including mixed and 
organic waste, and failure to sort waste can contribute to the growth of crow and raven populations in urban areas. The increase in the population is both a result and a symbol of crowded urban settlements [1]. However, the phenomenon may be limited to certain areas or countries. Some respondents noticed a reverse trend: the reduction of bird populations in cities.

The urbanization of natural landscapes is a global, accelerating phenomenon. It modifies the physical structure and ecological processes in primaeval habitats. Urbanization affects the landscape significantly and poses new challenges for life, often reducing biodiversity [50]. Bird habitats in cities are often found to offer poorer mixes of species compared to rural environments. They are often dominated by several, often alien species [51]. Urbanization leads to the homogenization of avian communities through local, rare species dying out and the same urban bird species growing in number over many large areas. Urban birds often persist thanks to a certain behavioral flexibility, which helps them to survive and breed close to human settlements [52].

Species remaining or colonizing and sometimes thriving in urban areas have been referred to as human commensals, urban exploiters, or synurbic species [53]. Some typical example species that remain in European cities include great tits (Parus major), European blackbirds (Turdus merula), and wood pigeons (Columba palumbus), which often persist at elevated densities during increasing degrees of urbanization [52]. European starlings (Sturnus vulgaris), house sparrows (Passer domesticus), and rock doves (Columba livia) are examples of species that colonize newly urbanized habitats from other built-up areas. There are also several corvid species that have been thriving in and around cities for a long time [54]. Several avian species, such as American crows (Corvus brachyrhynchos), house sparrows (Passer domesticus), European starlings (Sturnus vulgaris), and rock pigeons (Columba livia), generally increase their densities in response to urbanization across the globe [50]. Such contrasting responses to urbanization prompted urban ecologists to adopt the terms urban avoider, urban adapter, and urban exploiter to categorize species that, respectively, are absent from, persist in, and thrive in cities [55].

Birds are generally believed to have easier access to food in cities, but not all studies confirmed this. Several studies demonstrated that chicks from urban habitats are fed with smaller amounts or poorer quality food, which results in lower body weight compared to chicks in natural environments [56,57]. Lack of food can be caused by lower mortality rates among urban birds (no predators), which causes an abrupt increase in population size and overexploitation of resources [58].

Some bird species live successfully in urban habitats despite the potential negative nature of interactions with people [59,60]. Clucas et al. [60] conducted research in two cities: Berlin, Germany and Seattle, Washington, USA. They demonstrated that residents of both cities actively supported birds living in urban areas. According to Clucas et al. [60], their activities stemmed from demographic, cultural, and socioeconomic factors, but also general attitudes towards birds and environmental protection. This is consistent with the results presented by Kellert [61] indicating that populations of different birds exhibited diverse patterns of behavior in various parts of the world due to cultural differences in approaches to wild nature [61].

Respondents from Poland did not exhibit negative attitudes towards avifauna in urban areas, even though many of them associated birds with disorder, noise, and soiled elevations. They balanced these qualities with what could be described as nostalgia for birdsong and the presence of birds in cities. Note that the research focused on crows and ravens, and the results suggest that the birds live in Polish cities, in a way, "in parallel to humans". Y and Z generation respondents did not feed crows and ravens, just as they did not feed other bird species. At the same time, crows and ravens did not seem to "count on human help". Neither did the respondents demonstrate any hostile attitudes, such as actively scaring the birds away. This supports the conclusion that crows and ravens blend well into to the cultural landscape of urban Poland; they obtain food independently and remain "at a safe distance, out of people's way". The research by Clucas and Marzluff [62] demonstrated that this "specific distance" could result from both positive and negative behavior towards birds shaping their behavior. The effect could be particularly strong with crows and ravens, which are excellent observers, learn quickly, and share knowledge with their "companions". 


\section{Discussion on Research Questions and Hypothesis}

Socioeconomic changes can lead to birds, or other inhabitants of cities, living in a kind of "parallel reality". The research shows that many young respondents failed to notice urban ecosystem elements or did not pay attention to them. Urban life can, therefore, lead to people growing insensitive to the problems of organisms in urban ecosystems. Another contributing factor is technological development, which drives the young generation's shunning of natural environmental stimuli in favor of a digital reality and the interpretation of the world through popular culture. This may be of significance in the future when this generation completes its studies and takes managerial posts in governmental institutions or political jobs responsible for shaping environmental laws. Life in the urban pop-cultural environment can shape dubious attitudes and affect future decisions, which is why pro-environmental education is so important.

The research thesis was partially falsified. Representatives of Generation $\mathrm{Y}$ and $\mathrm{Z}$ are familiar with the symbolism of the crow and raven, sometimes more so than those aged 60 and over. This is partially due to the virtually unlimited access to information online and contact with popular culture, which draws extensively on the symbolism. Works of popular culture, films, video games, tabletop games, and music are sources of knowledge about the symbolism of the crow and raven for young adults today. The older generation refers to these sources much more rarely, if at all. This is why representatives of Generation $\mathrm{Y}$ and $\mathrm{Z}$ were able to provide many more examples of crows and ravens in myths and legends from works of popular culture. On the other hand, Generation $Y$ and $Z$ did not attach great weight to the symbolism. In a way, these generations are "used to" the symbolism. They are familiar with it but do not believe in it. For them, it is part of the fantastic domain.

Crows and ravens symbolize death, but today, this is "video-gaming and film death" where each character can be revived-a digital death, somewhat distant and less tangible. This may also be because most members of Generation $\mathrm{Y}$ and $\mathrm{Z}$ (respondents) have not experienced poverty, hunger, or war.

\section{Conclusions}

In general, the respondents perceived crows and ravens negatively. Even if some of them paid no heed to the birds, they reverted to stereotypes when asked about them. Most of the respondents were neutral towards crows and ravens. They often stated that they did not pay attention to them. Crows and ravens seem to "blend in" with the hustle and bustle of the city and become "invisible".

Young generation respondents were perfectly familiar with the symbolism of the crow and raven. They emphasized numerous times that they symbolized death, war, and misery. Only one person had positive associations with the birds because of childhood experience. The importance of crows and ravens has been deeply rooted in the human mind. It seems to be directly related to the interpretation of the appearance and behavior of the birds. The way in which knowledge and opinions about them are handed down has changed over centuries. Once, this took place through an oral tradition and individual observations; one could watch crows and ravens feeding on carrion or circling a house. Today, knowledge and popular beliefs are reinforced by school reading and popular culture, which mold opinions and attitudes. The perception of crows and ravens by the younger generation stems mostly from popular culture and their appearance and behavior. In a way, thousands of years of evolution of the birds have determined how they are perceived today, and there is nothing to suggest that this perception could change.

The crow and raven are ominous birds that herald bad luck and evoke negative associations and feelings in the consciousnesses of consecutive generations. The ways in which crows and ravens are represented in popular culture and perceived by the public may directly affect their fate in areas with human presence. The negative image of the crow and raven has been reinforced in works of popular culture, and this process continues through films, television series, or video games. This is particularly important in the case of young generations, which use online popular culture works as sources of knowledge. 
The crow and the raven have intrigued minds for years. When stimulated, the respondents often indicated the "metaphysical nature" of the birds, which are as much associated with mystery, supernatural powers, or magic as they were thousands of years ago. The respondents were polarized, however. Two attitudes dominated the survey: pragmatic and "metaphysical". The pragmatic respondents pointed out the role of crows and ravens in the urban ecosystem and attributed the supposedly "metaphysical" meaning to "medieval debris". The "metaphysical" respondents exhibited greater effort of thought focused on the cultural importance of the birds. They were able to see crows and ravens from the perspective of beliefs, myths, and legends. Such an approach to the birds could significantly affect their protection and future in cities. The pragmatic approach exhibits less tolerance, while the "metaphysical" position is more empathetic. It may be crucial for the protection and preservation of bird populations in urban areas, particularly in the context of resident education and the shaping of pro-environmental attitudes.

Author Contributions: Conceptualization, K.K.; methodology, K.K.; validation, K.K. and J.H.; formal analysis, K.K.; resources, K.K.; data curation, K.K.; writing-original draft preparation, K.K.; writing-review and editing, K.K.; visualization, K.K.; supervision, K.K. and J.H.; project administration, K.K.; funding acquisition J.H. All authors have read and agreed to the published version of the manuscript.

Funding: This study was financed by the Ministry of Science and Higher Education of the Republic of Poland under the project "Cultural heritage of small homelands" No. PPI/APM/2018/1/00010/U/001, financed by the Polish National Agency for Academic Exchange as part of the International Academic Partnerships.

Acknowledgments: The authors wish to thank Dariusz Zdonek from the Silesian University of Technology in Gliwice for his help with the survey. The paper was written at the Digital Cultural Heritage Laboratory, part of the Department of Land Management and Landscape Architecture at the Faculty of Environmental Engineering and Land Surveying of the University of Agriculture in Krakow, Poland.

Conflicts of Interest: The authors declare no conflict of interest. The funders had no role in the design of the study; in the collection, analyses, or interpretation of data; in the writing of the manuscript, or in the decision to publish the results.

\section{References}

1. Marzluff, J.M.; Angell, T. In the Company of Crows and Ravens; Yale University Press: New Haven, CT, USA, 2007.

2. Anjos, L. Family Corvidae (Crows). In Handbook of the Birds of the World. Bush-Shrikes to Old Sparrows; Hoyo, J., Elliot, A., Christie, D.A., Eds.; Lynx Edicions: Barcelona, Spain, 2009; Volume 14, pp. 494-640.

3. Jønsson, K.A.; Fabre, P.-H.; Irestedt, M. Brains, tools, innovation and biogeography in crows and ravens. BMC Evol. Biol. 2012, 12, 72. [CrossRef]

4. Sol, D.; Duncan, R.P.; Blackburn, T.M.; Cassey, P.; Lefebvre, L. Big brains, enhanced cognition, and response of birds to novel environments. Proc. Natl. Acad. Sci. USA 2005, 102, 5460-5465. [CrossRef]

5. Serjeantson, D.; Morris, J. Ravens and crows in iron age and roman britain. Oxf. J. Archaeol. 2011, 30, 85-107. [CrossRef]

6. Nihei, Y.; Higuchi, H. When and where did crows learn to use automobiles as nutcrackers? Tohoku Psychol. Folia 2001, 60, 93-97.

7. Marzluff, J.M.; Angell, T. Cultural Coevolution: How the Human Bond with Crows and Ravens Extends Theory and Raises New Questions. J. Ecol. Anthr. 2005, 9, 69-75. [CrossRef]

8. Wascher, C.A.F.; Bugnyar, T. Behavioral Responses to Inequity in Reward Distribution and Working Effort in Crows and Ravens. PLoS ONE 2013, 8, e56885. [CrossRef]

9. Sol, D.; Timmermans, S.; Lefebvre, L. Behavioural flexibility and invasion success in birds. Anim. Behav. 2002, 63, 495-502. [CrossRef]

10. Ratcliffe, D. The Raven: A Natural History in Britain and Ireland; Poyser: London, UK, 1997.

11. Wilmore, S.B. Crows, Jays, Ravens and Their Relatives; David \& Charles: Newton Abbot, UK, 1977.

12. Bugnyar, T.; Kotrschal, K. Leading a conspecific away from food in ravens (Corvus corax)? Anim. Cogn. 2004, 7, 69-76. [CrossRef]

13. Ross, A. Pagan Celtic Britain: Studies in Iconography and Tradition; Routledge: London, UK, 1974.

14. Aldhouse-Green, M.J.; Aldhouse-Green, S. The Quest for the Shaman: Shape-Shifters, Sorcerers, and Spirit-Healers of Ancient Europe; Thames \& Hudson: London, UK, 2005. 
15. Green, M.J. Animals in Celtic Life and Myth; Routledge: London, UK, 1992.

16. Honegger, T. Form and function: The beasts of battle revisited. Engl. Stud. 1998, 79, 289-298. [CrossRef]

17. Bukowick, K.E. Truth and Symbolism: Mythological Perspectives of the Wolf and Crow; Boston College: Chestnut Hill, MA, USA, 2004.

18. Biegeleisen, H. Śmierć w Obrzędach, Zwyczajach $i$ Wierzeniach Ludu Polskiego [Death in the Rituals, Customs and Beliefs of the Polish People]; Dom Książki Polskiej S-ka Akc.: Warszawa, Poland, 1930.

19. Da Silva, F.V. Red as blood, white as snow, black as crow: Chromatic symbolism of womanhood in fairy tales. Marvels Tales J. Fairy-Tale Stud. 2007, 21, 240-252.

20. Żeromski, S. Rozdzióbia Nas Kruki, Wrony [Ravens and Crows Will Peck Us to Pieces]; Nakładem Ksiegarni L. Zwolińskiego i Spółki: Kraków, Poland, 1896.

21. Fiore, I.; Tagliacozzo, A. I resti ossei animali dal santuario preromano in localitá"Fornace” di Altino (VE). In Culti e Santuari antichi in Altino e nel Veneto Orientale (Altinum, Studi e Ricerche Sulla Gallia Cisalpina 14, Studi di Archeologia, Epigrafia e Storia 2); del Sacro, G., Ed.; Quasar Edizioni: Rome, Italy, 2001; Volume 14, pp. 87-96.

22. Zeiler, J.T.; Vries, L.S. De Raaf in de Waterput. Archeozoölogisch Onderzoek van de Romeinse Stad Forum Hadriani (120-270 AD), Gem. Leidschendam-Voorburg (LVB-FO 9888); ArchaeoBone Rapport Nr: Leeuwarden, The Netherlands, 2008.

23. Woodward, P.; Woodward, A. Dedicating the town: Urban foundation deposits in Roman Britain. World Archaeol. 2004, 36, 68-86. [CrossRef]

24. Liker, A.; Papp, Z.; Bókony, V.; Lendvai, Á.Z. Lean birds in the city: Body size and condition of house sparrows along the urbanization gradient. J. Anim. Ecol. 2008, 77, 789-795. [CrossRef]

25. Jedlicka, J.A.; Greenberg, R.; Letourneau, D.K. Avian Conservation Practices Strengthen Ecosystem Services in California Vineyards. PLoS ONE 2011, 6, e27347. [CrossRef]

26. Wenny, D.G.; DeVault, T.L.; Johnson, M.D.; Kelly, D.; Sekercioglu, C.H.; Tomback, D.F.; Whelan, C.J. The Need to Quantify Ecosystem Services Provided by Birds. Auk 2011, 128, 1-14. [CrossRef]

27. Bocheński, M.; Ciebiera, O.; Dolata, P.T.; Jerzak, L.; Zbyryt, A. Ochrona Ptaków w Mieście [Protection of Birds in the City]; RDOŚ w Gorzowie Wielkopolskim: Gorzów Wielkopolski, Poland, 2013.

28. Hubacek, K.; Kronenberg, J. Synthesizing different perspectives on the value of urban ecosystem services. Landsc. Urban Plan. 2013, 109, 1-6. [CrossRef]

29. Kronenberg, J.; Bocheński, M.; Dolata, P.T.; Jerzak, L.; Profus, P.; Tobółka, M.; Tryjanowski, P.; Wuczyński, A.; Żołnierowicz, K.M. Znaczenie bociana białego Ciconia ciconia dla społeczeństwa: Analiza z perspektywy koncepcji usług ekosystemów. Chrońmy Przyr. Ojcz. 2013, 69, 179-203.

30. Wyrost, P. The fauna of ancient Poland in the light of archaeozoological research. In Skeletons in her Cupboard, Oxbow Monograph; Clason, A., Payne, S., Uerpmann, H.P., Eds.; Oxbow Books: Oxford, UK, 1993; Volume 34, pp. 251-259.

31. Haag-Wackernagel, D.; Geigenfeind, I. Protecting buildings against feral pigeons. Eur. J. Wildl. Res. 2008, 54, 715-721. [CrossRef]

32. Elmhurst, K.S.; Grady, K. Fauna Protection in a Sustainable University Campus: Bird-Window Collision Mitigation Strategies at Temple University. In Handbook of Theory and Practice of Sustainable Development in Higher Education; Leal Filho, W., Brandli, L., Castro, P., Newman, J., Eds.; World Sustainability Series; Springer International Publishing: Cham, Switzerland, 2017; Volume 1, pp. 69-82.

33. Król, K.; Kao, R.; Hernik, J. The Scarecrow as an Indicator of Changes in the Cultural Heritage of Rural Poland. Sustainability 2019, 11, 6857. [CrossRef]

34. Klem, D.; Farmer, C.J.; Delacretaz, N.; Gelb, Y.; Saenger, P.G. Architectural and Landscape Risk Factors Associated with Bird-glass Collisions in an Urban Environment. Wilson J. Ornithol. 2009, 121, 126-134. [CrossRef]

35. Davidov, E.; Depner, F. Testing for measurement equivalence of human values across online and paper-and-pencil surveys. Qual. Quant. 2009, 45, 375-390. [CrossRef]

36. Ozkan, M.; Solmaz, B. The Changing Face of the Employees-Generation Z and Their Perceptions of Work (A Study Applied to University Students). Procedia Econ. Financ. 2015, 26, 476-483. [CrossRef]

37. De Cooman, R.; Dries, N. Attracting Generation Y: How Work Values Predict Organizational Attraction in Graduating Students in Belgium. In Managing the New Workforce: International Perspectives on the Millennial Generation; Ng, E.S., Lyons, S., Schweitzer, L., Eds.; Edward Elgar Publishing: Northampton, MA, USA, 2012; pp. 42-63. 
38. Noble, S.M.; Haytko, D.L.; Phillips, J. What drives college-age Generation Y consumers? J. Bus. Res. 2009, 62, 617-628. [CrossRef]

39. Myers, K.K.; Sadaghiani, K. Millennials in the Workplace: A Communication Perspective on Millennials' Organizational Relationships and Performance. J. Bus. Psychol. 2010, 25, 225-238. [CrossRef] [PubMed]

40. Berkup, S.B. Working with Generations X and Y In Generation Z Period: Management Of Different Generations In Business Life. Mediterr. J. Soc. Sci. 2014, 5, 218. [CrossRef]

41. Bolton, R.N.; Parasuraman, A.; Hoefnagels, A.; Migchels, N.; Kabadayi, S.; Gruber, T.; Loureiro, Y.K.; Solnet, D. Understanding Generation $Y$ and their use of social media: A review and research agenda. J. Serv. Manag. 2013, 24, 245-267. [CrossRef]

42. Hardey, M. Generation C: Content, Creation, Connections and Choice. Int. J. Mark. Res. 2011, 53, 749-770. [CrossRef]

43. Levickaite, R. Y, X, Z Kartos: Pasaulio be sienu idejos formavimas naudojantis socialiniais tinklais (lietuvos atvejis). Creat. Stud. 2010, 3, 170-183. [CrossRef]

44. Frąckiewicz, E. Pokolenie $60+$ a pokolenie $\mathrm{Z}$ na rynku nowoczesnych usług bankowych. Zarzadzanie Finanse 2018, 16, 121-133.

45. LaRose, R.; Tsai, H.-Y.S. Completion rates and non-response error in online surveys: Comparing sweepstakes and pre-paid cash incentives in studies of online behavior. Comput. Hum. Behav. 2014, 34, 110-119. [CrossRef]

46. Bernal, R.; San-Jose, L.; Retolaza, J.L. Improvement Actions for a More Social and Sustainable Public Procurement: A Delphi Analysis. Sustainablity. 2019, 11, 4069. [CrossRef]

47. Chisika, S.N.; Park, J.; Yeom, C. The Impact of Legislation on Sustainability of Farm Forests in Kenya: The Case of Lugari Sub-County in Kakamega County, Kenya. Sustainability 2019, 12, 27. [CrossRef]

48. Barrios, M.; Villarroya, A.; Borrego, Á.; Ollé, C. Response Rates and Data Quality in Web and Mail Surveys Administered to PhD Holders. Soc. Sci. Comput. Rev. 2010, 29, 208-220. [CrossRef]

49. Madden, C.F.; Arroyo, B.; Amar, A. A review of the impacts of corvids on bird productivity and abundance. Ibis 2014, 157, 1-16. [CrossRef]

50. Bonier, F. Hormones in the city: Endocrine ecology of urban birds. Horm. Behav. 2012, 61, 763-772. [CrossRef]

51. Marzluff, J.M. Worldwide Urbanization and Its Effects on Birds. In Avian Ecology and Conservation in an Urbanizing World; Marzluff, J.M., Bowman, R., Donnelly, R., Eds.; Springer: Boston, MA, USA, 2001; pp. $19-47$.

52. Slabbekoorn, H. Songs of the city: Noise-dependent spectral plasticity in the acoustic phenotype of urban birds. Anim. Behav. 2013, 85, 1089-1099. [CrossRef]

53. Francis, R.A.; Chadwick, M.A. What makes a species synurbic? Appl. Geogr. 2012, 32, 514-521. [CrossRef]

54. Zmihorski, M.; Halba, R.; Mazgajski, T.D. Long-term spatio-temporal dynamics of corvids wintering in urban parks of Warsaw, Poland. Ornis Fennica 2010, 87, 61-68.

55. McKinney, M.L. Urbanization, Biodiversity, and ConservationThe impacts of urbanization on native species are poorly studied, but educating a highly urbanized human population about these impacts can greatly improve species conservation in all ecosystems. Bioscience 2002, 52, 883-890. [CrossRef]

56. Pierotti, R.; Annett, C. The Ecology of Western Gulls in Habitats Varying in Degree of Urban Influence. In Avian Ecology and Conservation in an Urbanizing World; Marzluff, J.M., Bowman, R., Donnelly, R., Eds.; Springer: Boston, MA, USA, 2001; pp. 307-329.

57. Mennechez, G.; Clergeau, P. Effect of urbanization on habitat generalists: Starlings not so flexible? Acta Oecol. 2006, 30, 182-191. [CrossRef]

58. Shochat, E. Credit or Debit? Resource Input Changes Population Dynamics of City-Slicker Birds. Oikos 2004, 106, 622-626. [CrossRef]

59. Clucas, B.; Marzluff, J.M.; Kübler, S.; Meffert, P. New Directions in Urban Avian Ecology: Reciprocal Connections between Birds and Humans in Cities. In Perspectives in Urban Ecology: Ecosystems and Interactions between Humans and Nature in the Metropolis of Berlin; Endlicher, W., Ed.; Springer: Berlin, Germany, 2011; pp. 167-195.

60. Clucas, B.; Rabotyagov, S.; Marzluff, J.M. How much is that birdie in my backyard? A cross-continental economic valuation of native urban songbirds. Urban Ecosyst. 2014, 18, 251-266. [CrossRef]

61. Kellert, S.R. Attitudes, Knowledge, and Behavior Toward Wildlife Among the Industrial Superpowers: United States, Japan, and Germany. J. Soc. Issues 1993, 49, 53-69. [CrossRef] 
62. Clucas, B.; Marzluff, J.M. Attitudes and actions toward birds in urban areas: Human cultural differences influence bird behavior. Auk 2012, 129, 8-16. [CrossRef]

Publisher's Note: MDPI stays neutral with regard to jurisdictional claims in published maps and institutional affiliations.

(C) 2020 by the authors. Licensee MDPI, Basel, Switzerland. This article is an open access article distributed under the terms and conditions of the Creative Commons Attribution (CC BY) license (http://creativecommons.org/licenses/by/4.0/). 